Family, State and Social Policy 
By the same author

PERSPECTIVES IN CHILD CARE POLICY 


\section{Family, State and Social Policy}

\section{LORRAINE FOX HARDING}

Consultant Editor: Jo Campling

\section{palgrave macmillan}




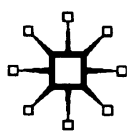

(c) Lorraine Harding 1996

Softcover reprint of the hardcover 1st edition 1996

All rights reserved. No reproduction, copy or transmission of this publication may be made without written permission.

No paragraph of this publication may be reproduced, copied or transmitted save with written permission or in accordance with the provisions of the Copyright, Designs and Patents Act 1988, or under the terms of any licence permitting limited copying issued by the Copyright Licensing Agency, 90 Tottenham Court Road, London W1T 4LP.

Any person who does any unauthorised act in relation to this publication may be liable to criminal prosecution and civil claims for damages.

The author has asserted her right to be identified as the author of this work in accordance with the Copyright, Designs and Patents Act 1988.

Published by

PALGRAVE MACMILLAN

Houndmills, Basingstoke, Hampshire RG21 6XS and

175 Fifth Avenue, New York, N. Y. 10010

Companies and representatives throughout the world

PALGRAVE MACMILLAN is the global academic imprint of the Palgrave Macmillan division of St. Martin's Press, LLC and of Palgrave Macmillan Ltd. Macmillan is a registered trademark in the United States, United Kingdom and other countries. Palgrave is a registered trademark in the European Union and other countries.

ISBN 978-0-333-57482-9

DOI 10.1007/978-1-349-24377-8

ISBN 978-1-349-24377-8 (eBook)

This book is printed on paper suitable for recycling and made from fully managed and sustained forest sources. Logging, pulping and manufacturing processes are expected to conform to the environmental regulations of the country of origin.

A catalogue record for this book is available from the British Library. 
This book is dedicated to my late father, the Reverend Walter Gill, who set me off on the academic and writing paths early in life 


\section{Contents}

Acknowledgements $\quad$ ix

Introduction $\quad \mathbf{x}$

1 Dimensions of Family Change: Gender,

Reproduction, Age and Generation 1

Gender 2

Reproduction $\quad 25$

Age and generation $\quad 36$

$\begin{array}{ll}\text { Conclusion } & 46\end{array}$

2 Dimensions of Family Change: Marriage $\begin{array}{ll}\text { Transformed } & 47\end{array}$

Marriage $\quad 48$

Divorce $\quad 52$

Consequences of divorce $\quad 62$

Alternatives to marriage? $\quad 75$

$\begin{array}{ll}\text { Conclusion } & 88\end{array}$

3 Continuity and Change $\quad 89$

$\begin{array}{lr}\text { Historical continuity } & 89\end{array}$

$\begin{array}{ll}\text { Historical change } & 91\end{array}$

$\begin{array}{ll}\text { Recent continuity } & 94\end{array}$

Recent change $\quad 98$

$\begin{array}{ll}\text { Continuity or change? } & 101\end{array}$

4 Areas of Interaction between Family and State 106

State-family interaction: control and support 107

$\begin{array}{ll}\text { Family law } & 111\end{array}$

Assumptions and influence in family law 126

$\begin{array}{ll}\text { Incomes policy and families } & 128\end{array}$ 
Assumptions and influence in incomes policy

Housing policy and families

Assumptions and influence in housing policy

Community care and families

Assumptions and influence in community care

Child care and families

Assumptions and influence in child care

The universal services of health and education, and families

Conclusion

5 Models of the Family-State Relationship

An authoritarian model of family-state relationship

A laissez-faire model of family-state relationship

Introduction to the intermediate models

Conclusion

6 The Quest for 'Family Policy'

204

Definitions of 'family policy'

205

Rhetoric and ideology versus reality and implementation in 'family policy'

212

'Family policy' as smokescreen and instrument

The problem of 'side-effects'; the case for 'family impact statements'

Inconsistencies, anomalies, contradictions: a coherent family policy?

Can 'family policy' be value-free?

Conclusion

Bibliography

Index 


\section{Acknowledgements}

I would like to acknowledge the help of the following in writing this book: Jo Campling for her unending encouragement and support; Andrew Green and colleagues in the International Division of the Nuffield Institute for Health, Leeds University, for housing me in 'the attic' while I wrote the bulk of this book; Norma Martin Clement of the School of Law, Leeds University, for advice and information on family law, and Jane Pillinger of Northern College for similar help on Europe; Linda Brooke and Carol-Lynn Strickland-Scott for help with references; Julia Wassall for word-processing the bibliography; Terry Wassall for converting the word-processor discs; Mary Lance for the invaluable task of editing and cutting; and, finally, Steve Harrison of the Nuffield Institute for Health for coming up with a brilliant idea every time I passed him in the corridor!

LORRAINE FOX HARDING 


\section{Introduction}

The key theme of this book is the relationship between family and state in conditions of rapid change. Political and media interest in family change, and the state's response to it (actual, possible or preferred), has intensified recurrently in the 1980s and early 1990s, and did so to a degree in the decades prior to that. In the 1970 s, for example, there were debates about family change, especially the needs of the growing group of single-parent families, and about possible 'family impact statements' to highlight the effects of government policies on families of different types. In Britain, both major political parties claimed to be 'the party of the family'. In the 1980s the tone of debate became somewhat more strident, with a backlash against sexual 'permissiveness' and the growth of alternatives to the traditional married family. 'Pro-family' movements, supporting a reversion to traditional forms, appeared on both sides of the Atlantic, and in Britain in 1983 a Cabinet group (called the Family Policy Group) reported on how 'the family' might be strengthened by various government measures. In 1987 an Executive Order from the Reagan Administration spoke of strengthening family stability, the marital commitment and parental responsibility. Later in the 1980s, the British government's expressed concern about the decline of the two-parent family paved the way for the Child Support Act 1991, which aimed to increase absent fathers' maintenance contributions. This was modelled on a scheme for child support set up in Wisconsin. Before this Act was fully operational, further concern about single parents was expressed by government ministers, with suggestions of additional policy change. From time to time the claim has been made that single parenthood occurs by choice, out of a desire to obtain various benefits from the welfare state (and that therefore such benefits should be reduced). In the USA this theme was associated by thinkers 
such as Murray (1984) with notions of a growing 'underclass', separated by its lifestyle and welfare dependence from mainstream society. During the 1990 s pro-family pressure groups and their publications attacked trends such as working mothers, easy divorce, cohabitation, and the apparent weakening of fatherhood and its alleged social consequences (for example, Dennis and Erdos, 1992). They wished to reinstate an earlier family form, perceived as more stable and socially beneficial. At the same time feminist writing and scholarship proliferated and was broadly critical of patriarchal family forms for their adverse effect on women. The debate polarised as family change appeared to accelerate, and was particularly sharp in North America where various types of family change were more advanced than in many west European states.

Dramatic change in families has occurred and continues to occur; this seems undeniable. But there were, and are, deep divisions over the meaning of change, its consequences and its policy implications. It is against this background that this book attempts to tease out the main areas of family change and their significance, what the state does to and for families through law and policy, and how the state's relationship with family life might be understood. The text covers events and legislation up to the time of writing (1994).

\section{Key terms}

Some key concepts in this book are 'family', 'state' and 'social policy', the first two of which are particularly problematic. Neither 'family' nor 'state' must be seen as a unitary concept with a single accepted meaning or reference point. Not only are there diverse family forms in modern society (single-parent, cohabiting and step-families, as well as the married, two parent nuclear form), but the notion of 'family' overlaps concepts such as household, kinship, marriage and parenthood; it may also be used metaphorically to describe, for example, a nation, collectivity or group. There are also different values and ideas about what families should be like, and what kind of living arrangement acceptably merits the term 'family'. The term 'the family' is on the whole avoided in this book (see Finch, 1989), as it contains certain values concerning the worth of a particular 
type of institution - the married, two-parent family form, gender-differentiated, stable through time - and assumptions about social stability which accompany the perception of that form. Alternative terms to 'the family' which perhaps do not carry the same connotations are family, families, and family life.

Second, 'state' is also a concept incorporating diverse meanings. The state, as Frost (1990) argues, is not a unified set of institutions or an internally coherent entity; and this is particularly the case in its relationship with the various family forms. The state is a set of institutions/organisations (such as central and local government departments, courts, the police and quasiautonomous agencies set up and funded by government) with other institutions - such as the professions - closely linked to it, each body having its own rules, policies and practices which are not necessarily consonant with each other, and do not necessarily reflect one ideology, aim or set of interests. As will be shown in Chapter 6, different practices towards families may be directly in conflict with each other; for example, a particular family form or family role may be rewarded in one part of the system but penalised in another. The 'messages' which the various state agencies give about family life are therefore mixed, often confusing and contradictory. The terms 'state' and 'the state' are used for convenience throughout this book, but it must be borne in mind that this many-armed, many-eyed entity does not move in one coordinated direction or speak with a single voice.

Third, policy is understood as the ongoing actions of state organisations which have a degree of stability and which affect many people's lives in significant ways. Policy in Britain includes Acts, statutory instruments, circulars, regulations, codes of practice, directives, reports and reviews, plans, statements of intent as in White Papers, and the thinking and principles which underpin these. Social policy specifically is concerned with social purposes and effects, including distribution of life chances, wellbeing and the quality of life, and also with the social consequences of other policies. With regard to families, policy acts on them but is also affected by how families form and behave. For example, an increase in single parents changes demands on the social security system and on public housing stock. Family members can redefine their own responsibilities in ways which 
then alter pressure on the state, and this is not entirely controllable by the state. Policies are the object of family behaviour, as families are (sometimes) the object of policies.

Families and the state have a complicated and uneasy relationship, with the effects of action and change working both ways. Many policies, not all of them 'social policies', affect family life (sometimes very significantly), but family functioning may also act on a range of policies. The term 'family policy', as will be shown in Chapter 6, has no clear-cut meaning, but may be a useful device for approaching developments in the actions of the state and their implications for families.

\section{Outline of the book}

The essential focus of this book is change in families and the interaction between family and state. It examines specific changes in family patterns such as gender and marriage, policies which impinge on families, and how state-family interaction may be understood. Chapters 1 and 2 focus on various aspects of family change: gender roles, the reproduction of children, ageing and inter-generational relationships, and changes relating to marriage. Chapter 3 addresses the significance of change, as opposed to continuity, in family relationships. Chapter 4 covers the interaction between families, the state and social policy in Britain. The areas examined include family law, incomes policy, housing, community care and child care. The chapter sets out the state of policies affecting families, and explores assumptions underlying policy and policies' influence on families. Policies and their assumptions constrain families but also support them in some ways. Chapter 5 examines seven hypothetical models of the state-family relationship on a continuum of greater and less control. The two extremes are represented by an authoritarian and a laissez-faire model, and the intermediate stages by enforcement of responsibilities; manipulation of incentives; working within constraining assumptions; substituting for/supporting families; and responding to needs and demands. Chapter 6 looks at the notion of 'family policy': the meaning of this term; the question of family rhetoric; 'family policy' as smokescreen for other policies; side-effects and the demand for family impact statements; inconsistency in policies; 
and briefly whether 'family policy' can be value-free.

Overall, the book will attempt to understand and clarify some aspects of changing family life and the state's role in that life, aspects that are clearly troubling to many people. It does not constitute a full and final interpretation of family change and the family-state relationship, or a prescription for where the family should go or how the state should attempt to get it there. 